\title{
都市における屋外気温変化が多種の疾患に与える影響の総合評価 COMPREHENSIVE EVALUATION OF THE INFLUENCE OF OUTDOOR TEMPERATURE CHANGE ON HUMAN HEALTH AROUND THE URBAN AREA
}

\author{
鳴海大典*1, 井原智 彦*2, 福田早苗*3, 下田吉之*4 \\ Daisuke NARUMI, Tomohiko IHARA, Sanae FUKUDA \\ and Yoshiyuki SHIMODA
}

\begin{abstract}
This paper aims to comprehensively and quantitatively evaluate the impact of urban outdoor temperature change on human health in Osaka Prefecture. The evaluation time range was the 1970s as the base period, the 1990s, the 2010s. Urban temperature change had a negative impact on health from the early summer to the early autumn, while a positive impact from late autumn to spring. The influence of sleep disturbance and fatigue had a large impact. Although the disability weight and the disease period are small for these disease, these influences are indispensable to evaluate the entire of health over the urban area.
\end{abstract}

Keywords : urban heat island, global warming, human health, impact analysis, LCIA ヒートアイランド, 地球温暖化, 健康, 被害評価, ライフサイクル評価

\section{1.はじめに}

我が国では過去 100 年間に全国（都市影響が比較的少ない 15 都 市) で年平均気温が $1.5 \mathrm{~K}$ 上昇し, 地球温暖化 $(\mathrm{GW})$ の影響と考え られている1).また, 主要な大都市ではヒートアイランド現象 (UHI) と GW の相乗影響により夏季の最高気温が約 1 2 K, 冬季の最低 気温が約 $3 \sim 6 \mathrm{~K}$ 上昇した ${ }^{1)}$. 主要都市の気温上昇率は 21 世紀以降 も依然として高く 1 , 近未来における昇温の継続は想像に難くない. 都心回帰が今後さらに顕著化し, 大都市圈の DID (Densely Inhabited District）を中心として UHI 影響が強まる可能性がある. 一方で, $\mathrm{CO}_{2}$ 濃度は世界的に増加の一途である ${ }^{2)}$. 特に OECD 加盟 国外での将来的な大幅増が予想され, GW 影響の拡大は不可避と考 えられる ${ }^{3)}$. GW は都市化の程度に影響されないため, 我が国にお いても非都市圈を含めて $\mathrm{GW}$ 影響の拡がりが懸念される.

UHI や GW による気温変化は当然のことながら都市生活者に多 様な影響を及ぼす，この点に関して，筆者ら $\left.{ }^{4}\right)$ は都市における気温 変化とその影響について全体像を連関図で示寸とともに, エネルギ 一・資源 5)6)や健康 78)99, 大気污染 10111)などに及ぼす影響を可能な限 り定量的かつ多面的に評価してきた. 得られた結果の一例として, エネルギーに関しては気温上昇が地域によっては需要減少に寄与寸 るために, 全国一律の UHI 対策が不適当であることや, 大気污染に 関しては光化学オキシダント濃度に影響を及ぼす植生 VOC の気温 依存性が高いことなどを示した。これらの検討に引き続き, 本論文
では都市生活者の健康面に与える影響について可能な限り総合的な 検討を試みる.

気象変化と健康との関連性については, 古くから疫学的, 生理学 的な検討が生気象学や医学を中心として行われており, 喘息やリウ マチ，季節性感情障害などに対する影響が明らかとなってきた 12)13)14)。しかしこれらは主に季節変化や気候区分などの影響に着目 するものであり，都市における屋外気温変化を対象とするものでは なかった.

都市における屋外気温変化と健康との関係について最も着目され るのは熱中症である.ヒートアイランド対策大綱 15)においても冒頭 で熱中症患者の増加が懸念として示されている. 代表的な研究とし て挙げられるのは中井 16)や藤部 17), 星ら 18)であり, 暑熱障害による 死亡について経年変化や発生場所の影響などが検討されている．ま た，建築を含めた要因分析が環境省によってなされている 19)。一方 で $\mathrm{GW}$ との関連で最も着目されるのは感染症であろう20).なかでも 媒介生物の増加や越冬により，マラリアやデング熱などの感染症が 増加すると指摘されている. 2014 年に東京都でデング熱の患者が確 認されたことも記憶に新しい21)，但し，この東京都における事例も 偶発的であり, 将来的にリスクが高まることが予想されるものの, その発生時期や場所を事前予測することは困難で不確実性が高い影 響と考えられる ${ }^{22)}$ 。一方で市民の実感としては, 真夏に経験する症 状として不眠や疲労・変調を挙げる割合が高く23)，屋外気温変化に

\footnotetext{
*1 横浜国立大学大学院環境情報研究院 准教授 ·博士 (工学)

*2 東京大学大学院新領域創成科学研究科 准教授 - 博士 (工学

*3 関西福祉科学大学健康福祉学部 教授 · 博士 (医学)

*4 大阪大学大学院工学研究科 教授 $\cdot$ 工博
}

Assoc. Prof., Graduate School of Environmental and Information Sciences, Yokohama National University, Dr.Eng.

Assoc. Prof., Dept. of Environment Systems, University of Tokyo, Dr.Eng. Prof., Dept. of Health and Welfare, Kansai University of Welfare Sciences, Dr.Med. Prof., Graduate School of Engineering, Osaka University, Dr.Eng. 
伴うこれらへの影響は重要な問題として位置づけられる. その他に は, 熱・寒冷ストレスを起因とする循環器疾患や呼吸器疾患に関わ る死亡リスクの変化 ${ }^{24)}$, 気温変化に伴う光化学オキシダント濃度変 化による死亡リスク 25)や喘息 26)への影響, さらには花粉症などのア レルギー患者の増加 ${ }^{27)}$ が可能性として指摘されている. 他方で, $\mathrm{UHI}$ や GW による気温変化は当然のことながら夏季のみならず年 間を通して影響を及ぼすことが予想される，すなわち，冬季には気 温が上昇することで, 例えば上述の寒冷ストレスを起因とする死亡 リスクが軽減される可能性の高いことに留意する必要がある ${ }^{24)}$.

以上のように, UHI や GW が健康に及ぼす影響について概観す るとともに代表的な検討事例を挙げたが，個別の具体的な疾患につ いてその要因分析や気温影響に関する定量評価が行われている一方 で，それらを体系的に整理した上で影響に関する定量評価を行った 事例は非常に少ないのが現状である. また, UHI や GW による気温 変化は冬季にも影響を及ぼすため, 健康に与える影響も年間を通し た評価が必要となる.

屋外気温変化と健康との関連性について, マスメディアや政府発 信の予防情報などが対象とするのは殆どが熱中症であり 28)，熱中症 以外の健康影響は軽視される傾向がある. 筆者らはこのような状況 を鑑みて,これまで都市における気温変化が感染症類 7)や睡眠 8)29), 疲労 9930)に与える影響を評価すると共に, リスク分析に必要となる 重篤度注1)の決定 31)などを進めてきた．本論文ではこれら筆者らが 蓄積したデータや既往研究の成果を基にして, 死亡に至る重篤な影 響から比較的軽度な影響までを総合的に年間評価することを目的と するものである.

\section{2. 健康影響評価の枠組み}

本論文では日本版被害算定型影響評価手法(Life-cycle Impact Assessment Method based on Endpoint Modeling, LIME) 32)に準 拠した井原ら 33)の手法を踏襲し, 様々な疾患注 2)による健康被害を 障害調整生存年(disability-adjusted life year, DALY) 注 3)を用いて 統合的に評価する.

\section{1 評価手順}

本研究の具体的な評価手順を以下に記す.まず第 1 段階として, 屋外気温変化と健康との関連性について, 既往研究の成果を基に評 価対象の枠組みを決定する (2.2 節)。続いて第 2 段階として, 評価 対象疾患の気温感応度を既往研究に基づき評価する (4.1 節から 4.3 節).さらに第 3 段階として, 既往研究による重篤度および有病期間 などのパラメータに基づき, 各疾患による被害量をDALYにより評 価する (4.1節から 4.3 節). なお, DALY と支払い意思額との関係 を基にして経済的な価值としての被害評価も可能であるが，支払い 意思額の決定には様々な課題も含まれることから，ここでは DALY の評価にとどめる. 最後に第 4 段階として, 得られた気温感応度を ある特定の地域の過去から現在にかけての気温偏差に乗じることで, 気温変化に伴う健康影響を疾患間で比較し，その影響の大小につい て比較を試みる ( 5 章)。

\section{2 評価対象疾患}

1 章で述べたように, 都市における気温変化は死亡に至る重度の ものから入院・通院を伴わない軽度のものまで, さまざまな水準の 影響を及ぼす.ここでは DALY を求める際に異なる手順を要するこ
とから「死亡に至る（レベル 1)」,「死亡に至らない（レベル 2)」の 2 水準に区分して影響評価対象を決定した。レベル別に本論文で評 価対象とした疾患を Table 1 に示す。これらの疾患を評価すること で，都市における気温変化が健康に与える影響を総合的に評価でき ると考えた 注 ${ }^{4}$. 評価対象の空間的範囲は UHI の影響が顕著であり， 健康影響の気温感度データが入手しや寸い大阪府全域とした。

レベル 1 については，前述の熱・寒冷ストレスを起因とする循環 器疾患や呼吸器疾患に関わる死亡リスクの変化に加えて, 死亡に至 る熱中症を採り上げた。なお，レベル 1 は生命損失年数(YLL) 注 3$)$ により DALYを評価する，レベル 2 については各種感染症，睡眠困 難, 疲労, 死亡に至らない熱中症を採り上げた。各種感染症に関し て, 対象とする疾患の選定方法は 4.2 で後述する.レベル 2 は相当 損失年数(YLD) 注3)により DALY を評価する。なお，各評価対象に 関する分析方法などは 4 章で後述する.

\section{3 気象データ}

4 章では各疾患の影響分析を，5章では被害分析をそれぞれ大阪 府全域を対象として実施するが，両分析における基準気温には AMeDAS 大阪観測所の観測データを使用する，なお，各疾患の評価 指標に関して, 睡眠困難は午前 0 時の結果を, 各種感染症は週間平 均気温を，それ以外の疾患は日最高気温を用いる。

\section{3．熱中症の重篤度}

YLD の評価には重篤度と有病期間が必要だが，レベル 2 の死亡 に至らない熱中症は GBD(Global Burden of Disease)データベース 34)に設定がない。そこで，既往研究の手法を参考に，内科医に対す るアンケート調査を通じて重篤度の決定を試みた。なお，本調查で は同時に睡眠困難，疲労についても調査を行い重篤度を決定してい る ${ }^{31)}$.

GBD や Stouthard et al. ${ }^{35)}$ での事例では, 人得失法(person tradeoff）注 5)を用いて重篤度を決定するが, 質問数が多く回答者に多大な 負担を掛ける問題がある。一方で，Müller-Wenk ${ }^{36}$ によよる軽度なも のから重度なものまでを含む 28 種類の他の疾患と比較させる方法 注 6)では，質問紙も簡素であり，回答者の負担も小さい利点がある. そこで Müller-Wenk の質問票を参考に，基準となる複数疾患の重 篤度を回答者に提示した上で，熱中症の重篤度を相対的に評価させ た．基準に関しては，Müller-Wenk が採用した疾患に対して「統合

Table 1 Evaluated disease or disturbance and its disability level

\begin{tabular}{|c|c|c|c|}
\hline Level & & Disease, Disturbance & $\begin{array}{c}\text { Disability } \\
\text { weight }\end{array}$ \\
\hline \multirow{2}{*}{$\begin{array}{c}\text { Death } \\
\text { (Level1) }\end{array}$} & \multicolumn{2}{|c|}{ Heat/Cold stress (65 and pver) } & $\begin{array}{ll}1.00 \\
\end{array}$ \\
\hline & \multicolumn{2}{|c|}{ Death by Heatstroke (under 65) } & 1.00 \\
\hline \multirow{10}{*}{$\begin{array}{c}\text { Not death } \\
\text { (Level2) }\end{array}$} & \multirow{7}{*}{ Infections } & Herpangina & 0.16 \\
\hline & & Hand, foot and mouth disease & 0.17 \\
\hline & & Pharyngo-conjunctival fever & 0.12 \\
\hline & & Escherichia coli & 0.22 \\
\hline & & \begin{tabular}{|l|} 
Gastroenteritis \\
\end{tabular} & 0.11 \\
\hline & & Keratoconjunctivitis & 0.09 \\
\hline & & Exanthema subitum & 0.13 \\
\hline & \multicolumn{2}{|c|}{ Sleep disturbance } & 0.069 \\
\hline & \multicolumn{2}{|c|}{ Fatigue } & 0.05 \\
\hline & \multicolumn{2}{|c|}{ Heatstroke (Not death) } & 0.14 \\
\hline
\end{tabular}


Table 2 Determination of the disability weight of heatstroke

\begin{tabular}{|c|c|c|c|c|}
\hline \multirow{2}{*}{ Level } & \multicolumn{2}{|c|}{ N } & \multicolumn{2}{c|}{ Disability weight } \\
\cline { 2 - 6 } & - & Outliers & Average $(95 \% \mathrm{CI})$ & Max. \\
\hline \hline Stage1 (Heat cramps) & 40 & 11 & $0.081(0.062-0.100)$ & 0.2 \\
\hline Stage2 (Heat exhaustion) & 49 & 2 & $0.237(0.185-0.288)$ & 0.6 \\
\hline Stage3 (Heat stroke) & 51 & 0 & $0.463(0.379-0.546)$ & - \\
\hline
\end{tabular}

失調症」,「鬱」,「原発性睡眠障害」を加えた全 31 種類とした.アン ケート対象者は一般開業内科医とし, 温暖化影響を受ける東京およ び大阪, 名古屋圈在住, 3 年以上の臨床経験を有する者を対象とし た. 調查対象者は医療情報専門会社である M 3 Inc.によってインタ 一ネットを介して募集した. なお, 本調査は上述のように睡眠困難, 疲労と同時に実施したものであり, 設問内容など調查手法の詳細に 関しては Fukuda et al. ${ }^{31)}$ を参照されたい。

調查対象人数は 70 名, 得られた有効回答数は 51 サンプルであ

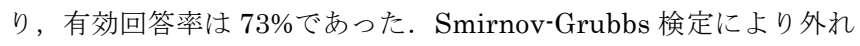
值を除外した上で, 重篤度の平均值を求めた. なお, 熱中症は医学 的側面から I 度から III度までの重症度分類 37)があり, 本調查におい ても各分類で重篤度を定義したＩI 度は軽症であり熱けいれんや熱 失神と定義され，II 度は中等症であり熱疲労，III度は重症であり熱 射病と一般的には定義される。国立環境研究所による重症度別の熱 中症患者数データ 38 )によると，I 度の患者数は全体の $63 \%$, II 度は $35 \%$, III度は $2 \%$ を占め, 軽度の患者割合が高い值を示している. 得られた結果を Table 2 に示寸. 重篤度の平均值は I 度が 0.081 , II 度が 0.237 , III度が 0.463 となり, 障害程度が上がるにつれて重 篤度も高い值を示した注 7). 調查の際に提示した疾患リストとの比較 では, I 度は軽症安定狭心症 (I20 注 8) ), II 度は神経障害を伴う糖尿 病 $\left(\mathrm{E} 10.4-\mathrm{E} 14.4^{\text {注 } 8)}\right)$, III 度は重度の視力障害 $(\mathrm{H} 54.0$ 注 8) $)$ と同程 度と判断された。

\section{4. 影響分析}

本章では Table 1 に示した評価の枠組みに従い, 各疾患に対する 影響分析を筆者らが蓄積したデータや既往研究の成果を基に実施す る. 具体的には大阪府全域を評価範囲として屋外気温とDALY の関 係を評価する。

\section{1 死亡に至る（レベル 1)}

\section{a）熱・寒冷ストレスによる死亡}

Honda et al. ${ }^{39}$ は我が国の人口動態統計死亡票を解析し, 日最高 外気温と 65 歳以上の死亡率の関係を明らかにしている.その結果, 多くの都道府県で屋外気温と死亡率との関係は $\mathrm{V}$ 字型を示し, 例え ば東京における至適気温（ $\mathrm{V}$ 字の最小）は $30.5^{\circ} \mathrm{C}$ であり，それより も高いもしくは低い気温段階で死亡率が増加した. 人口動態統計の 死亡票はすべての死亡を対象としているため, すべての疾患による 死亡がここで取り扱われている。 しかし，上述のようにこの死亡率 の増加は循環系や呼吸系, 消化系の疾患をもっている者, それらの 予備力注 9)が低下した高齢者が熱中症に至るまえに循環不全で死亡 した結果と考えられている ${ }^{24)}$. 本論文ではこの Honda et al.のデー 夕を基にして, 大阪府における日最高外気温と熱・寒冷ストレスに よる死亡者数との関係から気温感度を定量化した. なお, Kunst et al. ${ }^{40)}$ は寒冷側の影響の半分は呼吸器系疾患の増加によるものであ

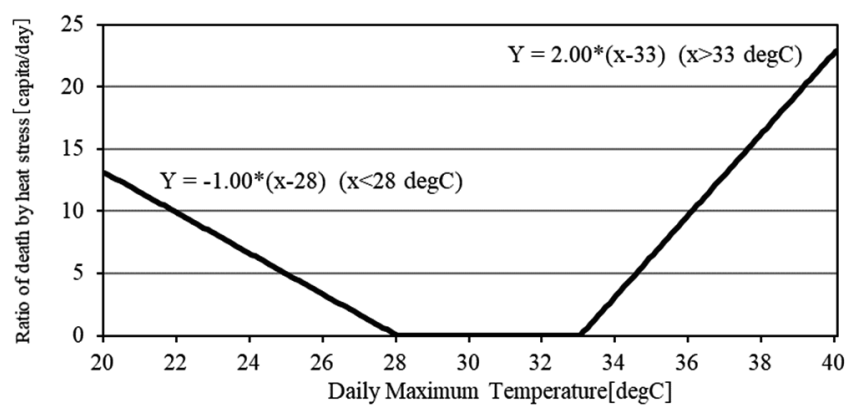

Fig. 1 Relationship between daily max. temperature and number of deaths due to heat / cold stress over 65s (Osaka Pref.)

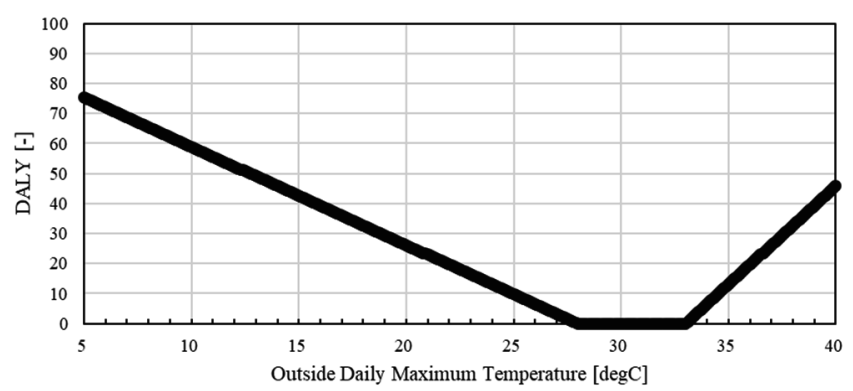

Fig. 2 Relationship between daily max. temperature and DALY (death due to heat / cold stress over 65s Osaka Pref.)

り，寒冷ストレスにあたらないことを指摘しており，本論文でも寒 冷側については $1 / 2$ を乗じている. 以上のプロセスで得られた日最 高外気温と 65 歳以上の死亡リスクとの関係を Fig. 1 に示す.

このような熱ストレスに対する脆弱性を起因とする死亡事象には 刈り取り効果(harvesting effect) 注 10)が働くことが予想されること から, 本項の死亡事象に関わる YLL は LIMEにならい 2 年とした. 以上のパラメータを基に推計された日最高外気温と DALY との関 係を Fig. 2 に示す.

b) 熱中症による死亡

上述の Honda et al. ${ }^{39}$ は 65 歳以上を対象としており，65 歳未満 の年齢階級は死亡率が低い上に刈り取り効果が小さいこともあり, 日最高外気温との明確な関係がみられないことが指摘されている 41)。一方で，熱中症に関しては小野 42)による死亡統計が存在する. 本論文ではこのデータを用い，日最高外気温と 65 歳未満の熱中症 による死亡者数との関係から気温感度を定量化した，なお，小野に よるデータは 65 歳以上を含むため, 同時期の人口動態統計死亡デ 一タから 65 歳未満の死亡者比率を求めて除外寸る補正を行った. 得られた結果を Fig. 3 に示す.

熱中症による死亡に関する YLL は，大阪府における年代別平均 余命と小野による年代別熱中症死亡比率を基にして, 平均余命をこ の死亡比率で重み付けすることで推定した. 結果としてYLLは 27.4

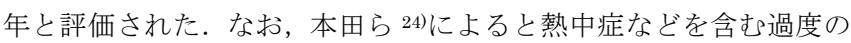
高温による死亡数は $1 \%$ 未満であり，上述の熱ストレスと比較して 圧倒的に割合は低い，以上のパラメータを基に推計された日最高外 気温とDALY との関係を Fig. 4 に示す.

\section{2 死亡に至らない（レベル 2）}

a) 感染症類

感染症に関しては屋外気温との関連性を網羅的に調查した事例が 


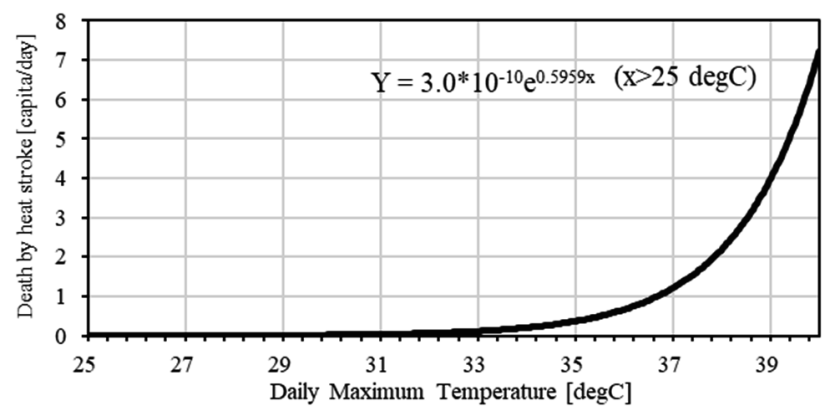

Fig. 3 Relationship between daily max. temperature and number of deaths by heatstroke under 65 s (Osaka Pref.)

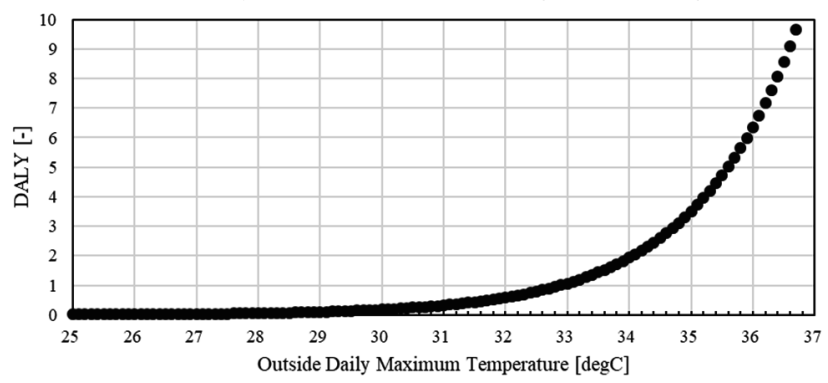

Fig. 4 Relationship between daily max. temperature and DALY (death by heatstroke under 65s, Osaka Pref.)

みられない，そこで筆者ら 7は大阪市保健所から提供を受けた感染 症発生動向調査データを基にして, 各種感染症の発症数と屋外気温 との関係を分析した注 ${ }^{11)}$. 感染症発生動向調查とは厚生労働省が感 染症の予防や流行予測のために, 87 種類の感染症に関して報告数を 集計するものである. 本研究の分析対象は 87 種類のうち, 感染症 発生動向調查事業年報の週別報告数から明確な季節変動が認められ, 気温との関連性があると考えられる 16 項目を第一段階として選定 した. 分析対象とした感染症を Table 3 に示寸. 16 項目のうち, 細 菌性赤痢と腸管出血性大腸菌感染症は全医療機関に報告が義務付け られており全数の把握が可能であるが，インフルエンザは府内 295 ヶ所, 流行性角結膜炎は 52 ヶ所, その他の感染症は 195 ヶ所の定 点 (指定医療機関) からの報告数が把握されている注 12 ). なお、報告 数は全て 1 週間毎に集計されている.

Table 3 に示寸 16 項目に関して, 週平均気温と週別日平均気温と の相関関係から 1 次関数もしくは指数関数による回帰式を求めた. 得られた回帰式を Table 3 に示寸. 分析対象とした 16 項目中で相 関性が認められたのは 7 項目のみであり, ヘルパンギーナ・手足口 病 - 咽頭結膜炎 - 腸管出血性大腸炎感染症 - 感染症胃腸炎 - 流行性 角結膜炎・突発性発疹の 7 疾患は気温感度が有意であると評価され た，そのうち感染性胃腸炎は気温と負の相関が, それ以外の感染症 では全て気温と正の相関が認められた。インフルエンザに関しては 気温との相関関係は認められなかったが, 週平均気温が約 $10^{\circ} \mathrm{C}$ 以下 になると報告数が増加することがわかった．本論文ではこれらの回 帰式から気温感度を定量化した注 ${ }^{13)}$. 重篤度と有病期間に関しては Table 3 のように設定したが，感染性胃腸炎の重篤度については GBD の記載から, その他の重篤度に関しては GBD に記載がないこ とから，GBDに記載のある類似疾患より適宜設定した注 ${ }^{14)}$. 有病期 間については臨床における平均罹患期間を医学資料を基にして設定
Table 3 Relationship between the number of occurrences of various infectious diseases and temperature

\begin{tabular}{|l|c|l|c|c|}
\hline \multicolumn{1}{|c|}{ Disease } & $\begin{array}{c}\text { Correla } \\
\text { tion }\end{array}$ & Approximation [range of use] & $\mathrm{R}^{2}$ & $\begin{array}{c}\text { Ill period } \\
\text { (day) }\end{array}$ \\
\hline \hline Herpangina & $\mathrm{P}$ & $\begin{array}{l}\mathrm{y}=0.13 \mathrm{e}^{\wedge}(0.25 \mathrm{x}) \\
{\left[\mathrm{May}-\mathrm{July} \text { and } 20-27^{\circ} \mathrm{C}\right]}\end{array}$ & 0.77 & 8 \\
\hline Hand, foot and mouth disease & $\mathrm{P}$ & $\mathrm{y}=0.22 \mathrm{e}^{\wedge}(0.16 \mathrm{x})\left[\mathrm{over} 22^{\circ} \mathrm{C}\right]$ & 0.46 & 10 \\
\hline Influenza & - & - & - & - \\
\hline Chickenpox & - & - & - & - \\
\hline Measles & - & - & - & - \\
\hline Epidemic parotiditis & - & - & - & - \\
\hline Rubella & - & - & - & - \\
\hline Pharyngo-conjunctival fever & $\mathrm{P}$ & $\mathrm{y}=0.41 \mathrm{e}^{\wedge}(0.12 \mathrm{x})\left[\mathrm{over} 21^{\circ} \mathrm{C}\right]$ & 0.49 & 6 \\
\hline Whooping cough & - & - & - & - \\
\hline Bacillary dysentery & - & - & - & - \\
\hline Escherichia coli & $\mathrm{P}$ & $\mathrm{y}=0.047 \mathrm{x}-0.27$ & 0.46 & 7 \\
\hline Erythema infectiosum & - & - & - & - \\
\hline Group A streptococcal pharyngitis & - & & - & - \\
\hline Gastroenteritis & $\mathrm{N}$ & $\mathrm{y}=-7.4 \mathrm{x}+279$ & 0.52 & 2 \\
\hline Keratoconjunctivitis & $\mathrm{P}$ & $\mathrm{y}=0.074 \mathrm{x}+1.7$ & 0.28 & 14 \\
\hline Exanthema subitum & $\mathrm{P}$ & $\mathrm{y}=0.30 \mathrm{x}+12$ & 0.43 & 5 \\
\hline $\begin{array}{l}\text { P: Posivite, N: Negative, - } \text { No correlation } \\
\text { y: daily average occurance, } \mathrm{x} \text { : weekly average temp. }\left[{ }^{\circ} \mathrm{C}\right]\end{array}$ & & \\
\hline
\end{tabular}

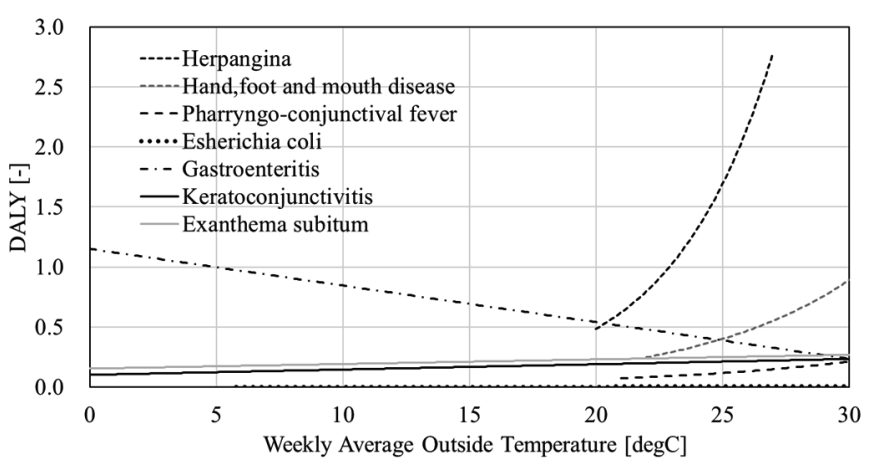

Fig. 5 Relationship between daily max. temperature and DALY (infections, Osaka Pref.)

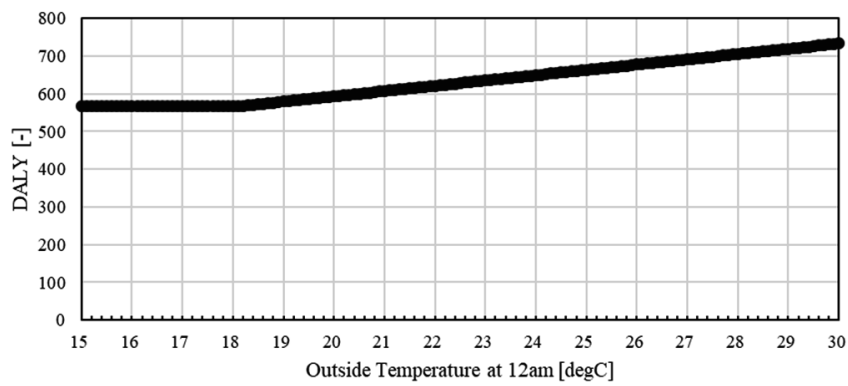

Fig. 6 Relationship between outside temperature at 12 midnight and DALY (sleep disturbance, Osaka Pref.)

した. 以上のパラメータを基に推計された週平均気温と DALY との 関係を Fig. 5 に示す.

b) 睡眠困難

鳴海らは夏季や冬季の異なる季節の中で，屋外気温の変化が睡眠 困難に与える影響をアンケート調査により明らかにしている ${ }^{8)}$. 調 查は 2010 年 7 月下旬から 10 月上旬までの夏季と 11 月下旬から 3 月上旬までの冬季に大別して実施された。調査対象者は大阪府内に 居住する 20 歳以上の男女約 600 名（各期延べ人数）である. なお, 調查方法の詳細ならびに結果は鳴海ら 8)を参照されたい.

本調查では，過去 1 か月の睡眠を問う日本語版ピッツバーグ睡眠 質問票(PSQI-J) 43)を応用した Sleep Quality Index for Daily Sleep (SQIDS) 29)を用いて評価しており, SQIDS はスコアが高くなるほど 
睡眠が困難な状況にあることを示す．調査結果から SQIDS スコア を基に日々の睡眠困難による有症率を求めた結果，0 時外気温が $18.1^{\circ} \mathrm{C}$ 以上で $1^{\circ} \mathrm{C}$ 当たり $0.84 \%$ の有症者が増加すると推定された. 本論文ではこのデータを用いて 0 時外気温と推定有症率との関係か ら睡眠困難に関する気温感度を定量化した。

睡眠困難による重篤度については，筆者らが実施した 6 名の専門 家（睡眠医学 4 名, 精神医学 2 名）に対するヒアリング結果から軽 度の睡眠困難に相当する 0.069 を設定した。得られた結果について は Fukuda et al. ${ }^{31)}$ で報告しており, 調査方法も含めて参照された い, 有病期間については, 気温変化に伴う睡眠困難は当日のみに影 響を及ぼすこと, アンケート調査による影響判定は日ごとであった ことも勘案し, 本論文では 1 日に設定した. 以上のパラメータを基 に推計された 0 時外気温とDALY との関係を Fig. 6 に示すと, 屋 外気温に依存しない被害が一定数（DALY で 567）存在し，上述の 気温閾值から被害量が変化することがわかる.

c) 疲労

上述の睡眠困難に関する調查では疲労に関する調查も併せて実施 している. 調查方法の詳細ならびに結果は鳴海ら9)を参照されたい. 本調査では Chalder の疲労尺度日本語版（CF スコア）44)を基に した Daily Chalder 総合得点(DCF スコア)で疲労状況を評価してお り, DCF スコアから日々の有症率を求めた結果, 日最高外気温が $12.0^{\circ} \mathrm{C}$ 未満では $1^{\circ} \mathrm{C}$ 上昇当たり $0.70 \%$ の有症者が減少する一方で, 日最高外気温が $24.2^{\circ} \mathrm{C}$ 以上では $1^{\circ} \mathrm{C}$ 上昇当たり $0.76 \%$ の有症者が増 加すると推定された．本論文ではこのデータを用いて日最高外気温 と推定有症率との関係から疲労に関寸る気温感度を定量化した。

疲労による重篤度については, 筆者らが実施した 7 名の専門家(疲 労医学 5 名, 精神医学 2 名) に対するヒアリング結果から, 気温变 化によって起こる短期的な疲労として 0.05 を選択した. 得られた結 果は Fukuda et al. ${ }^{31}$ で報告している．有病期間については，睡眠困 難と同様に 1 日とした. 以上のパラメータを基に推計された日最高 外気温と DALY との関係を Fig. 7 に示すと, 屋外気温に依存しない 被害が一定数（DALYで 418）存在し, 上述の気温閾值から被害量 が変化することがわかる.

d）死亡に至らない熱中症

4.1 節の b 項では死亡に至る熱中症について扱ったが, 2011 年か ら 2016 年の 7 年間における熱中症死亡数は平均で 942 人であるの に対して, 救急搬送者数は 49,384 人と 50 倍を超える. そこで本論 文では，国立環境研究所による救急搬送熱中症患者データ 45)のうち， 2004 2009 年度の大阪市における搬送データを用いて日最高外気 温と熱中症搬送者数との関係から死亡に至らない熱中症に関する気 温感度を定量化した注 ${ }^{15)}$. 得られた結果を Fig. 8 に示寸.

重篤度は Table 2 に示したとおりである. 有病期間に関しては, 日本救急医学会 46 に による重症度別の入院日数報告から重症度別平 均入院日数を算出し, 重症度ごとにその平均期間を有病期間と設定 した結果，I 度では 3.9 日，II 度では 4.2 日，III度では 7.4 日と推 定された。これらの值を基にして, 最終的には国立環境研究所 ${ }^{38)}$ に よる重症度患者比率から重篤度と有病期間の重み平均を求めた結果, 重篤度は 0.14 , 有病期間は 4.03 日と設定された. 以上のパラメー 夕を基に推計された日最高外気温とDALY との関係を Fig. 9 に示 す.

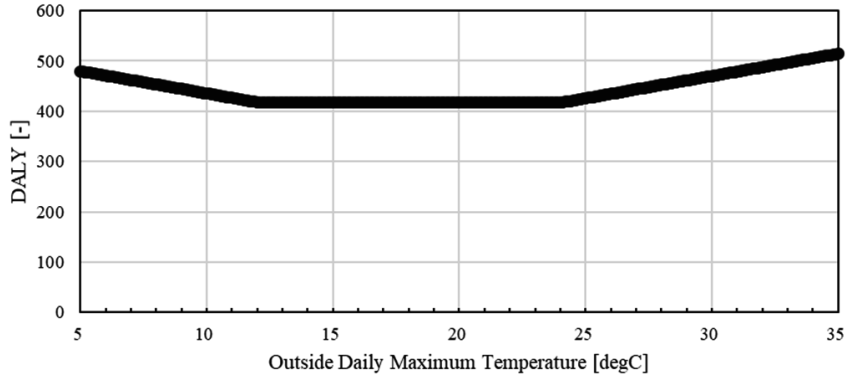

Fig. 7 Relationship between daily max. temperature and DALY (sleep fatigue, Osaka Pref.)

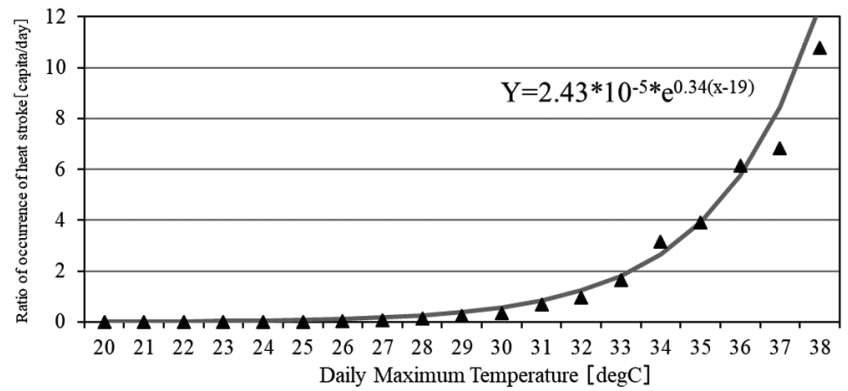

Fig. 8 Relationship between daily max. temperature and emergency ambulance transport number due to heat stroke (Osaka Pref.)

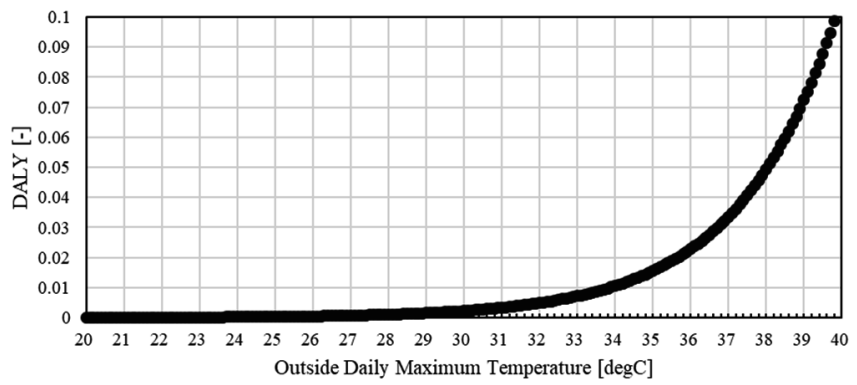

Fig. 9 Relationship between daily max. temperature and DALY (mild heatstroke, Osaka Pref.)

\section{5. 被害分析}

\section{1 分析条件}

本章では 4 章で得られた屋外気温とDALY との関係を基にして, UHI や GW の影響により過去から現在にかけて変化した屋外気温 が各疾患の DALYに与える影響を総合評価する注 ${ }^{16)}$. 評価対象とす る時間的範囲に関しては, 1967 年から 1977 年 (中央年 : 1972 年, 以降 1970 年代と表記）を基準期間として, 1987 年から 1997 年 (中 央年: 1992 年, 以降 1990 年代と表記), さらには 2007 年から 2017 年（中央年 : 2012 年, 以降 2010 年代と表記）の過去 40 年間（中 央年で）とする. 40 年間の気温変化について, Fig. 10 に日最高外 気温, Fig. 11 に午前 0 時の外気温の比較結果をそれぞれ示す. 折れ 線は各年代について 11 年間の平均值を, 棒グラフはそれらの差を 示している.

日最高外気温と比較して若干 0 時外気温の上昇幅が大きな值を示 した． 0 時外気温については 1 月に逆転がみられるが，その他の月 では概衩経年的に気温が上昇した。一方で，日最高外気温について は 1990 年代で 4 月および 5 月に気温の低下がみられることや，初 冬季（11月から 1 月）に 1990 年代の気温が最も高くなるなど，そ 


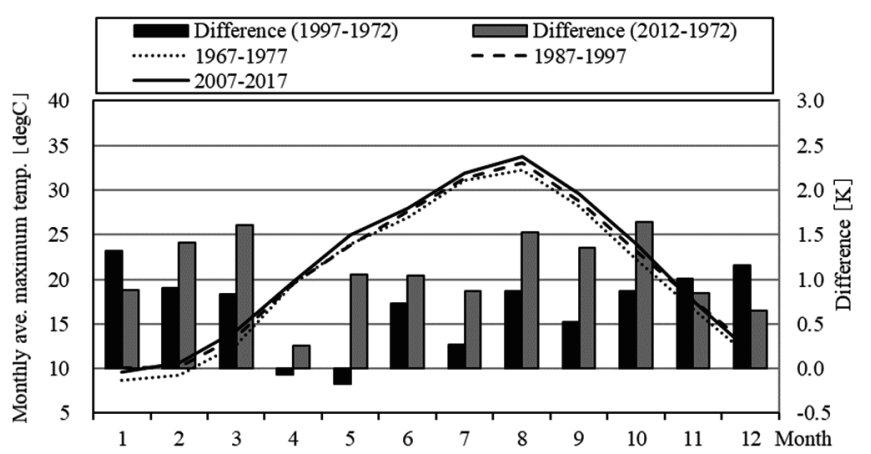

Fig. 10 Secular change in monthly average of daily max. temperature (Osaka Pref.)

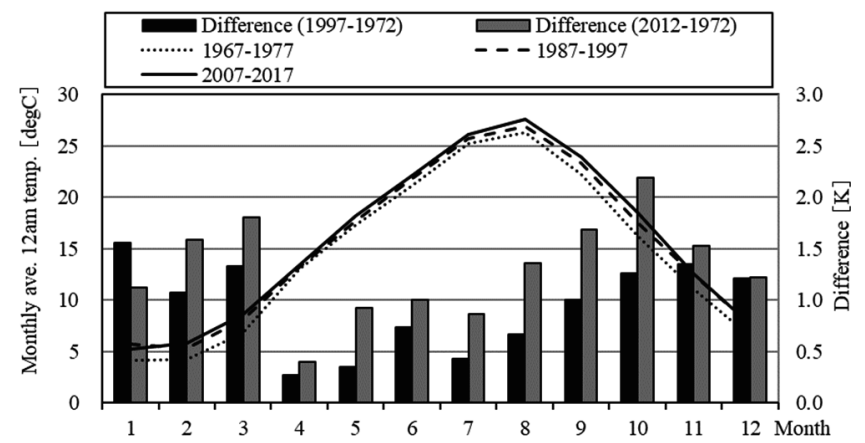

Fig. 11 Secular change in monthly average of temperature at 12 midnight (Osaka Pref.)

の変化傾向は 0 時外気温と比較してややばらつきが確認された.

\section{2 評価結果}

Table 4 に各年代における各疾患の DALY 評価結果を示す. 各疾 患に対して各年代（11 年間）の平均值, 最大值, 最小值, さらには 1970 年代を基準として 1990 年代, 2010 年代の変化率を各表下段 に記載している. また, 年間評価に加えて典型的な冬季の 2 月と夏 季の 8 月についても同様の值を記載している. 以下, レベル毎に結
果を整理する.

a）死亡に至る（レベル 1)

熱ストレスに関しては，年間評価の平均值では概衫線形的に DALY が増加する一方で，最大值は 1990 年代および 2010 年代の ともに倍程度の増加がみられるが，各年代を通じての最大值は記録 的な猛暑に見舞われた 1994 年であり，必ずしも経年変化傾向と一 致しないことに留意が必要である．2月はいずれの年代も影響はみ られない. 8 月は特に 2010 年代の平均值の増加が 1970 年代と比較 して 3 倍弱と顕著であり，夏季には熱ストレスが安定的に強まって いることがわかる． 8 月のみでは 2010 年に最大值を記録した。

寒冷ストレスに関しては, 年間評価の平均值では減少傾向にあり, 特に 1990 年代にかけての減少が顕著である. 1990 年代の年間値は 1970 年代と比較して $6 \%, 2010$ 年代の年間值は 1970 年代と比較し て 9\%と絶対量が非常に大きいために減少率は小さいが，差は熱ス トレスと比べて 2 倍程度と大きな影響を持つ. 年間評価の最大值や 最小值は平均值とほぼ同様の変化を示した. 2 月の変化傾向は年間 評価とほぼ同様であった。寒冷ストレスは $28^{\circ} \mathrm{C}$ を閾值とするため 8 月にも若干影響はみられるが值は非常に小さい.

熱中症（死亡に至る）に関しては，平均值の評価においては熱ス トレスと同様の傾向を示すとともに, 絶対量についても同程度の值 となった. 年間評価の最大值は 1994 年に記録し, 1970 年代と比較 して 2.5 倍程度であった. 8 月のみでも最大值は 1994 年であった. 本項目は指数関数で気温感度が定義されるため, 特に日最高外気温 が $37^{\circ} \mathrm{C}$ を超える極度な暑熱により最大值が熱ストレスに比べて上 昇しやすい傾向がみられた.

b）死亡に至らない（レベル 2)

Table 4 では対象とする全ての感染症をまとめて感染症類として 評価している．結果的には全評価期間を通して絶対量が小さく，ま た年代変化や気温変化の影響が弱い結果となった。項目毎では 2 月 には感冒性胃腸炎の影響によってDALYが減少した。 月情足 口病の影響によってDALY が増加した。なお表は割愛するが，季節 性かつ特定の気温帯のみで相関性が確認されるへルパンギーナは,

Table 4 Evaluation results of DALY for each disease or disturbance in each period

\begin{tabular}{|c|c|c|c|c|c|c|c|c|c|c|c|c|c|c|c|c|c|c|c|c|c|}
\hline \multirow{2}{*}{$\begin{array}{c}\text { Disease or } \\
\text { Disturbance }\end{array}$} & \multirow[b]{2}{*}{ index } & \multicolumn{3}{|c|}{ Annual } & \multicolumn{3}{|c|}{ February } & \multicolumn{3}{|c|}{ August } & \multirow{2}{*}{$\begin{array}{l}\text { Disease or } \\
\text { Disturbance }\end{array}$} & \multirow[b]{2}{*}{ index } & \multicolumn{3}{|c|}{ Annual } & \multicolumn{3}{|c|}{ February } & \multicolumn{3}{|c|}{ August } \\
\hline & & $\begin{array}{c}1967 \text { to } \\
1977 \\
\end{array}$ & $\begin{array}{c}1987 \text { to } \\
1997 \\
\end{array}$ & $\begin{array}{c}2007 \text { to } \\
2017 \\
\end{array}$ & $\begin{array}{c}1967 \text { to } \\
1977\end{array}$ & $\begin{array}{c}1987 \text { to } \\
1997\end{array}$ & $\begin{array}{c}2007 \text { to } \\
2017\end{array}$ & $\begin{array}{c}1967 \text { to } \\
1977\end{array}$ & $\begin{array}{c}1987 \text { to } \\
1997 \\
\end{array}$ & $\begin{array}{c}2007 \text { to } \\
2017\end{array}$ & & & $\begin{array}{c}1967 \text { to } \\
1977\end{array}$ & $\begin{array}{c}1987 \text { to } \\
1997 \\
\end{array}$ & $\begin{array}{c}2007 \text { to } \\
2017\end{array}$ & $\begin{array}{c}1967 \text { to } \\
1977 \\
\end{array}$ & $\begin{array}{c}1987 \text { to } \\
1997 \\
\end{array}$ & $\begin{array}{c}2007 \text { to } \\
2017\end{array}$ & $\begin{array}{c}1967 \text { to } \\
1977\end{array}$ & $\begin{array}{c}1987 \text { to } \\
1997\end{array}$ & $\begin{array}{c}2007 \text { to } \\
2017 \\
\end{array}$ \\
\hline \multirow{6}{*}{$\begin{array}{c}\text { Heat stress } \\
\text { (death) }\end{array}$} & \multirow{2}{*}{ Avg. } & \multirow{2}{*}{191.1} & 309.6 & 443.7 & \multirow{2}{*}{0.0} & 0.0 & 0.0 & \multirow{2}{*}{105.8} & 182.4 & 289.4 & \multirow{6}{*}{$\begin{array}{c}\text { Sleep } \\
\text { disturbance }\end{array}$} & \multirow{2}{*}{ Avg. } & \multirow{2}{*}{10311.6} & 11749.2 & 12946.5 & \multirow{2}{*}{0.3} & 0.4 & 0.4 & \multirow{2}{*}{3556.6} & 3845.2 & 4147.7 \\
\hline & & & $62 \%$ & $132 \%$ & & $0 \%$ & $0 \%$ & & $72 \%$ & $173 \%$ & & & & $14 \%$ & $26 \%$ & & $50 \%$ & $50 \%$ & & $8 \%$ & $17 \%$ \\
\hline & \multirow{2}{*}{ Max. } & \multirow{2}{*}{401.1} & 797.5 & 745.2 & \multirow{2}{*}{0.0} & 0.0 & 0.0 & \multirow{2}{*}{221.1} & 440.3 & 484.8 & & \multirow{2}{*}{ Max. } & 11870.2 & 15139.5 & 14376.4 & 2.8 & 4.2 & 4.2 & 4026.7 & 4669.4 & 4680.6 \\
\hline & & & $99 \%$ & $86 \%$ & & $0 \%$ & $0 \%$ & & $99 \%$ & $119 \%$ & & & 11870.2 & $28 \%$ & $21 \%$ & 2.8 & $50 \%$ & $50 \%$ & 4026.7 & $16 \%$ & $16 \%$ \\
\hline & Min. & 63.5 & 62.2 & 182.5 & 0.0 & 0.0 & 0.0 & 32.1 & 34.7 & 58.2 & & Min. & 8599.5 & 9151.2 & 11482.4 & 0.0 & 0.0 & 0.0 & 32133 & 3052.3 & 3722.9 \\
\hline & Nome & 0.3 & $-2 \%$ & $188 \%$ & 0.0 & $0 \%$ & $0 \%$ & & $8 \%$ & $82 \%$ & & VIIIII. & 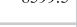 & $6 \%$ & $34 \%$ & 0.0 & $0 \%$ & $0 \%$ & 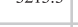 & $-5 \%$ & $16 \%$ \\
\hline & Ayg & 102165 & 9567 & 9272 & 17337 & 1650.6 & 1603.5 & 11.6 & 3.7 & 2.9 & & Ayg & 92237 & 8986.8 & 9976.6 & 8295 & 600.3 & 545.4 & 22291 & 2469.0 & 2648.3 \\
\hline Cold stress & Max & 107060 & 10208.5 & 10022.0 & 19553 & 1833.2 & 1859.4 & 337 & 20.0 & 10.8 & Farigue & Max. & 111923 & 11366.9 & 11631.8 & 12477. & 892.4 & 950.0 & 26709 & 2995.2 & 3060.8 \\
\hline (death) & . & 10700.0 & $-5 \%$ & $-6 \%$ & $193 . .5$ & $-6 \%$ & $-5 \%$ & 30.1 & $-41 \%$ & $-68 \%$ & 1 angut & inax. & 1119L. & $2 \%$ & $4 \%$ & 124.1 & $-28 \%$ & $-24 \%$ & $20 / 0.3$ & $12 \%$ & $15 \%$ \\
\hline & Min. & 9461.6 & 8941.8 & 8565.6 & 15346 & 1469.8 & 1369.7 & 0.0 & 0.0 & 0.0 & & Min. & 7397.7 & 6857.2 & 8756.2 & 440.4 & 325.2 & 199.4 & 1875.1 & 1841.5 & 2096.7 \\
\hline & . & 9401.0 & $-5 \%$ & $-9 \%$ & 103.0 & $-4 \%$ & $-11 \%$ & 0.0 & $0 \%$ & $0 \%$ & & 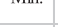 & 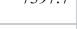 & $-7 \%$ & $18 \%$ & 470.4 & $-26 \%$ & $-55 \%$ & $10 / .1$ & $-2 \%$ & $12 \%$ \\
\hline & Ayg. & 141.9 & 222.0 & 299.5 & 00 & 0.0 & 0.0 & 700 & 124.5 & 185.7 & & Ayg & 06 & 0.7 & 0.9 & 00 & 0.0 & 0.0 & 02 & 0.4 & 0.4 \\
\hline & Avg. & 141.9 & $57 \%$ & $111 \%$ & 0.0 & $0 \%$ & $0 \%$ & 10.0 & $78 \%$ & $166 \%$ & & Avg. & 0.0 & $28 \%$ & $60 \%$ & 0.0 & $0 \%$ & $0 \%$ & 0.2 & $40 \%$ & $85 \%$ \\
\hline Heatstroke & Max & 255.2 & 621.0 & 487.1 & 0.0 & 0.0 & 0.0 & 1227 & 358.1 & 349.5 & Heatstroke & Max. & 0.7 & 1.3 & 1.1 & 00 & 0.0 & 0.0 & 04 & 0.7 & 0.7 \\
\hline (death) & Wiax. & 250.2 & $143 \%$ & $91 \%$ & 0.0 & $0 \%$ & $0 \%$ & 122.1 & $192 \%$ & $185 \%$ & (mild) & Nax. & 0.1 & $66 \%$ & $43 \%$ & 0.0 & $0 \%$ & $0 \%$ & 0.4 & $84 \%$ & $83 \%$ \\
\hline & Min. & 746 & 63.5 & 151.2 & 0.0 & 0.0 & 0.0 & 330 & 30.7 & 47.4 & & Min & 0.4 & 0.4 & 0.6 & 0.0 & 0.0 & 0.0 & 0.2 & 0.2 & 0.2 \\
\hline & Min. & 14.0 & $-15 \%$ & $103 \%$ & 0.0 & $0 \%$ & $0 \%$ & 33.0 & $-7 \%$ & $44 \%$ & & Min. & 0.4 & $-9 \%$ & $65 \%$ & 0.0 & $0 \%$ & $-6 \%$ & 0.2 & $-6 \%$ & $32 \%$ \\
\hline & Avg. & 08.5 & $1 \%$ & $0 \%$ & 5.1 & $-2 \%$ & $-2 \%$ & 0. & $5 \%$ & $9 \%$ & & Avg. & & $2 \%$ & $9 \%$ & 2508.1 & $-12 \%$ & $-16 \%$ & $39 / 9.8$ & $11 \%$ & $22 \%$ \\
\hline Infections & Max. & 73.7 & 72.9 & 72.7 & 53 & 5.2 & 5.2 & 69 & 7.7 & 7.7 & Total & Max. & 33029.2 & 36938.9 & 36553.9 & 3208.3 & 2730.8 & 2814.6 & 6995.8 & 8303.8 & 8504.0 \\
\hline IItections & Mad. & 15.1 & $-1 \%$ & $-1 \%$ & 3.3 & $-3 \%$ & $-3 \%$ & 0.9 & $10 \%$ & $10 \%$ & Total & & & $12 \%$ & $11 \%$ & & $-15 \%$ & $-12 \%$ & 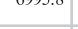 & $19 \%$ & $22 \%$ \\
\hline & Min. & 65.7 & 65.6 & 65.4 & 4.9 & 4.9 & 4.8 & 6.1 & 5.9 & 6.4 & & Min. & 26700.5 & 26100.5 & 29777.7 & 19827 & 1799.9 & 1573.9 & 51732 & 4972.7 & 6001.6 \\
\hline & & & $0 \%$ & $-1 \%$ & 4.9 & $-2 \%$ & $-2 \%$ & 6.1 & $-3 \%$ & $6 \%$ & & Min. & $26 / 00.3$ & $-2 \%$ & $12 \%$ & 1982.1 & $-21 \%$ & $-4 \%$ & $31 / 3.2$ & $-4 \%$ & $16 \%$ \\
\hline
\end{tabular}




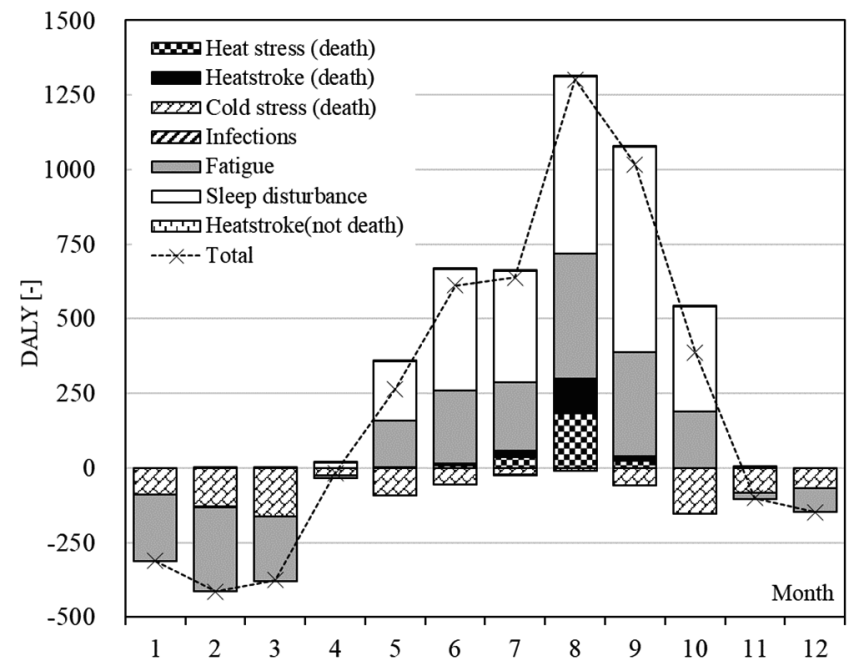

Fig. 12 Monthly evaluation of changing DALY due to outside temperature change in Osaka Pref. for 40 years (from the 1970's to the 2010's)

5 月と 6 月で大幅に増加する一方, 7 月は気温帯が外れることから 被害量が減少した。

睡眠困難に関しては注 ${ }^{17)}$, 年間評価および 8 月の平均值で概ね線 形的に DALY が増加した. 年間評価の平均值の増加率は年代間で 14\%程度とそれほど大きくないが, 寒冷ストレスと同様に絶対量が 大きく, その差は寒冷ストレスと比較しても顕著に大きい. 各年代 を通じての最大值は 1995 年に記録しており, 日最高外気温を变数 とする熱ストレスや熱中症（死亡）とは異なる結果となった。年間 評価の最小值は 2010 年代に大きく増加しており, 近年は安定して 夜間気温が上昇していることを示寸結果である.

疲労に関しては注 ${ }^{17)}$ ，年間評価は全ての指標で変化率が小さくな った。これは絶対量が多いことに加えて, 気温上昇に伴い冬季は減 少, 夏季は増加することで相殺されるためである. 絶対量は睡眠困 難や寒冷ストレスと同程度の大きな值を示した。 2 月は減少, 8 月 は増加を示したが, 特に冬季の閾值は日最高外気温で $12^{\circ} \mathrm{C}$ とや低 めであるため, 冬季と比べて夏季の変化量が大きくなった. 各年代 を通じての最大值は 2010 年に記録した。

熱中症（死亡に至らない）に関しては, 感染症と比較しても絶対 量は圧倒的に小さく，その影響はごくわずかであった。

c）健康影響の総合評価

以上を総合して, 過去 40 年間の気温変化によって生じる健康全 般に与える影響を全疾患の合計值で評価する. 年間評価の平均值で は特に 1990 年代から 2010 年代にかけての増加が顕著であり, 1970 年代から 1990 年代にかけての変化に比べて 4 倍程度となった. 後 述する 8 月と比べて変化量が大きく, 暑さのピークだけでなく初夏 から晚夏にかけて全体的に気温が上昇することで大きな影響がみら れた。一方で各年代を通じての最大值は 1994 年に記録しており， 経年変化傾向とは若干異なり, 突発的な猛暑の影響が強いことがわ かる. 最小值によると, 1990 年代には 1970 年代を下回る值を示す こともあったが, 2010 年代の最小值は 1970 年代の平均值と同程度 であり，全体的に影響が強まっていることがわかる．2月にはいず れの指標も減少傾向にあるが, 特に 1970 年代から 1990 年代にか
けての減少率が大きな值を示した. 8 月においてもやはり最小値の 増加が顕著である.

Fig. 12 に 2010 年代と 1970 年代の差について月別に評価した結 果を示す．上述のように感染症類や死亡に至らない熱中症の DALY は非常に小さく判別が困難である。結果によると，この 40 年間の 気温変化によって 5 月から 10 月までは DALY の合計值が増加する 一方で， 11 月から 4 月までは減少した。すなわち, 初夏から初秋ま では健康に対して悪影響になる一方で，晚秋から春にかけては良い 影響を与えていることが示された。ただし，中間期である 4 月や 11 月の影響は非常に小さい. 5 月から 10 月にかけても寒冷ストレスの 軽減はみられるが，悪影響に相殺されている．DALYの増加側で最 も変化が大きいのは 8 月であり, 中でも睡眠困難や疲労, 熱ストレ スによる死亡，熱中症による死亡が大きな值を示した，減少側で最 も変化が大きいのは 2 月であり, 疲労や寒冷ストレスによる死亡が 大きな值を示した。年間合計では 2,854 [DALY]の増加となった. DALY の変化には睡眠困難や疲労の影響が非常に大きく, 一人あた りのDALY，つまり重篤度や有病期間は小さいが，都市全体でのマ クロな視点では多くの市民に影響を与える疾患の影響が無視できな いことが示された.

\section{6.おわりに}

本論文は都市における屋外気温変化が健康に与える影響について 総合的かつ定量的な評価を行うことを目的に，筆者らが蓄積したデ 一タや既往研究の成果を基にして, 死亡に至る重篤な影響から比較 的軽度な影響まで年間を通した評価を行った。具体的には被害算定 型ライフサイクル影響評価手法の概念に基づき，様々な疾患による 健康被害をDALYを用いて統合的に評価した。評価対象の空間的範 囲は UHI の影響が顕著であり, 健康影響の気温感度データが入手 しやすい大阪府全域とした，得られた知見を以下に記す。

1）Müller-Wenk の手法を参考に，内科医に対するアンケート調査を 通じて死亡に至らない熱中症の重篤度を決定した結果，重篤度の平 均值は I 度が $0.081 ，$ II 度が 0.237 , III 度が 0.463 であった。

2）気温変化の影響を受ける疾患を 2 水準に区分し, 各疾患の気温感 度を基にして気温指標 (日最高外気温もしくは 0 時外気温) と DALY との関係を評価した。

3）年間評価の DALY の平均值は特に 1990 年代から 2010 年代にか けての増加が顕著であり，1970 年代から 1990 年代にかけての変化 の約 4 倍であった.

4）各年代を通じての最大值は 1994 年に記録しており，突発的な猛 暑の影響が強く, 安定的に増加する平均值とは傾向が異なることが 示された。

5） 2010 年代の最小值は 1970 年代の平均值と同程度であり，近年は 極端に低い值を示さないことが明らかとなった。

6） 40 年間の気温変化により 5 月から 10 月までは合計值が増加する 一方で，11月から 4 月までは減少した。これは都市の気温変化は夏 から秋にかけて健康に悪影響を及ぼす一方で，晚秋から春にかけて は良い影響を与えることを示している。

7） DALY の増加側で最も変化が大きいのは 8 月であり, 特に睡眠困 難や疲労, 熱ストレスによる死亡, 熱中症による死亡が大きな值を 示した，一方，減少側で最も変化が大きいのは 2 月であり，特に疲 
労や寒冷ストレスの緩和が大きな影響を与えた. DALY の年間合計 は増加であった。

8）睡眠困難や疲労の影響は DALY の変化に非常に大きな影響を与 えた。これらは一人あたりの值は小さいが, 都市全体でのマクロな 視点では影響が無視できないことが示された.

今後の課題としては, 注 4 や注 11 でも述べたように, 光化学才 キシダント濃度上昇に伴う喘息や死亡リスクの変化, 花粉飛散量の 変化に伴う花粉症への影響, さらには現時点では不確実性の高いデ ング熱など生物が媒介する感染症の影響など, 将来も見据えて包括 的に健康影響を評価するためには, 現時点の枠組みからさらに評価 対象疾患を拡大した検討が必要になると考えられる.この点に関連

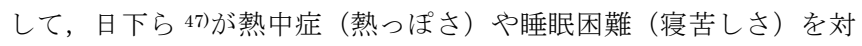
象として検討しているように, 将来気候変動が都市における包括的 な健康影響評価にどのような影響を与えるかについても検討が必要 になると考えられる.

\section{謝辞}

本研究の一部は科研費基盤研究 (B) 23360437 ならびに大林財団 研究助成の支援を受けた. データ解析においては大阪大学下田研究 室宮沢和貴君（当時博士前期課程大学院生）ならびに横浜国立大学 鳴海研究室秋山雄君（当時博士前期課程大学院生）の協力を得た. また, 国土交通省の健康維持増進住宅研究委員会 (委員長 : 村上周 三）での議論を通して貴重なご意見を頂いた，関係各位に感謝の意 を表す.

\section{参考文献}

1) The Japan Meteorological Agency: Climate Change Monitoring Report 2016, Chap.2 Climate Change, pp.37-57, 2017.7 (in Japanese)

2) World Meteorological Organization: WMO Greenhouse Gas Bulletin, 2017.10

3) Intergovernmental Panel on Climate Change: Fifth Assessment Report: Climate Change, 2013.11

4) Y. Shimoda, D. Narumi, M. Mizuno: Environmental Impact of Urban Heat Island Phenomena - Cause-effect Chain and Evaluation in Osaka City -, Journal of Life Cycle Assessment, Japan, pp.144-148, 2005.7

5) D. Narumi, Y. Niurao, Y. Shimoda, M. Mizuno: Effects of Increasing Temperature on the Regional Energy Consumption in Osaka Pref., Journal of Environmental Engineering (Transactions of AIJ), No.613, pp.71-78, 2007.3 (in Japanese)

6) D. Narumi, S. Hashimoto, Y. Shimoda, M. Mizuno: Regional Characteristics of the Effect of Temperature upon the Energy Consumption, Energy and Resources, No.166, pp.45-51, 2007.11 (in Japanese)

7) A. Kadobayashi, Y. Niurao, D. Narumi, Y. Shimoda, M. Mizuno: How the Air Temperature Change in Urban Region Influences Human Health, Technical Papers of Kinki-chapter Meeting the Society of Heating,Air-conditioning and Sanitary Engineers of Japan, pp.25-28, 2007.3 (in Japanese)

8) D. Narumi, T. Ihara, S. Fukuda: Study on the Impact for Sleep Disturbance Due to Changing Urban Outdoor Temperature, AIJ Journal of Technology and Design, No.52, pp.1045-1048, 2016.10 (in Japanese)

9) D. Narumi, T. Ihara, S. Fukuda: Study on the Impact for Fatigue Due to Changing Urban Outdoor Temperature, AIJ Journal of Technology and Design, No.54, pp.563-566, 2017.6 (in Japanese)

10) D. Narumi, Y. Shimoda, A. Kondo: The Effect of the Increase in Urban Temperature on the Concentration of Photochemical Oxidants, Atmospheric Environment, Vol.43, Issue14, pp.2348-2359, 2009.5

11) H. Bao, A. Kondo, A. Kaga, M. Tada, K. Sakaguchi, Y. Inoue, Y. Shimoda, D. Narumi, T. Machimura: Biogenic Volatile Organic Compound Emission Potential of Forests and Paddy Fields in the Kinki Region of Japan, Environmental Research, Vol.106, Issue2, pp.156-169, 2008.2
12) A. Nakayama (Editor): Thermophysiology, Rikogakusha Publishing Co.,Ltd., 1981.1 (in Japanese)

13) Y. Fukuoka, M. Yoshino: Weather Proverbs Related to Health-disease and their Seasonal Characters, AIRIES, Vol.17, No.1, pp.83-89, 2012. (in Japanese)

14) T. Miura: Climate, Temperature and Health, The Ohara Memorial Institute for Science of Labour, 1985.7 (in Japanese)

15) Inter-ministry Coordination Committee to Mitigate Urban Heat island: Outline of the Policy Framework to Reduce Urban Heat Island Effects, 2004.3 (in Japanese)

16) S. Nakai: Number of Deaths from Heat Stroke and Meteorological Condition - A Survey of the Last 21 Years in Japan -, Japanese Journal of Biometeorology 30(4), pp.169-177, 1993.10 (in Japanese)

17) F. Fujibe: Long-term Variations in Heat Mortality and Summer Temperature in Japan, TENKI, 60(5), pp.371-382, 2013.5 (in Japanese)

18) A. Hoshi, Y. Inaba: Mortality Rate of Heat Disorder Analyzed by Place of Occurrence Using Vital Statistics in Japan, Japanese Journal of Biometeorology, 39(1,2), pp.37-46, 2002. (in Japanese)

19) Ministry of the Environment, Government of Japan: Research Work Report of the Relationship Analysis of Heat Stroke and Heat Island Phenomena in FY 2010, pp.15-46, 2011.3 (in Japanese)

20) Ministry of the Environment, Government of Japan: Global Warming and Infectious Diseases, 2005. (in Japanese)

21) N. Seki and more of 17 people: An Autochthonous Outbreak of Dengue Type 1 in Tokyo, Japan 2014, Japanese Journal of Public Health, 62(5), pp.238-250, 2011.3 (in Japanese)

22) IPCC: Impacts, Adaptations and Mitigation of Climate Change: ScientificTechnical Analyses, 2001.

23) National Institute of Environmental Studies, Japan: Questionnaire on Global Warming (online), available from $<$ http://www.nies.go.jp/impact/jp_quest.html>, (accessed 2015. 8. 9). (in Japanese)

24) Y Honda, K. Takahashi: Health Effect of Heat Stress, AIRIES, Vol.14, No.2, pp.257-262, 2009. (in Japanese)

25) K. Tamura, Y. Matsumoto, K. Sasaki, T. Tsubaki: Global Warming and Air Pollution: The Influence on the Photochemical Oxidant Concentration and the Excess Death Risk, AIRIES, Vol.14, No.2, pp.271-277, 2009. (in Japanese)

26) S. Yamazaki, M. Shima, M. Ando, H. Nitta: Modifying Effect of Age on the Association between Ambient Ozone and Nighttime Primary Care Visits Due to Asthma Attack, J Epidemiol, 19(3), pp.143-151, 2009

27) K. M. Shea, R. T. Truckner, R. W. Weber, D. B. Peden: Climate Change and Allergic Disease, Journal of Allergy and Clinical Immunology, Vol.122, Issue3, pp.443-453, 2008.9

28) T. Itoigawa: The Effect of Measures for Preventing Heatstroke: Efforts of Municipality, Journal of Environmental Engineering (Transactions of AIJ), No.716, pp.993-1000, 2015.10 (in Japanese)

29) Y. Okano, T. Ihara, Y. Genchi: Evaluation of Environmental Impacts on Disturbed Sleep by Nighttime Urban Heat Island Phenomena Using Surveys via the Internet, Journal of Heat Island Institute International, Vol.3, pp.2233, 2008. (in Japanese)

30) H. Fujii, S. Fukuda, D. Narumi, T. Ihara, Y. Watanabe: Fatigue and Sleep under Large Summer Temperature Differences, Environmental Research, Vol.138, pp.17-21, 2015

31) S. Fukuda, T. Ihara, Y. Genchi, D. Narumi: Japanese Sleep Disturbance and Fatigue Disability Weights in Evaluating the Effects of Increasing Temperatures on Health by a Life Cycle Approach, International Journal of Life Cycle Assessment, No.18, pp.1089-1097, 2013.2

32) N. Itsubo, A. Inaba (Editor): Life Cycle Environmental Impact Assessment Method, Japan Environmental Management Association for Industry, 2005. (in Japanese)

33) T. Ihara, Y. Genchi: Environmental Impact Assessment of Urban Heat Island Phenomena Based on Endpoint-type Life Cycle Impact Assessment Methodology, Journal of Environmental Engineering (Transactions of AIJ), No.634, pp.1407-1415, 2008.10 (in Japanese)

34) World Health Organization: Global Burden of Disease 2004 Update Disability Weights for Diseases and Conditions, 2004 
35) M. E. A. Stouthard et al.: Disability Weights for Diseases in the Netherlands, Amsterdam: Inst. Sociale Geneeskunde, 1997.

36) R. Müller-Wenk et al.: Attribution to Road Traffic of the Impact of Noise on Health, Environmental Series, No.339, Swiss Agency for the Environment, Forests and Landscape (SAEFL), 2002.

37) S. Yasuoka, M. Akai, T. Ariga: Proposal of Heat Stroke (Heat Disorder) 1 to 3 Degree Classification: Clinical Significance of New Classification of Heatstroke, Emergency Medicine, Vol.23, pp.1119-1123, 1999.9 (in Japanese)

38) National Institute of Environmental Studies, Japan: Breaking Report of Heat Stroke Patients 2015, 2016 (in Japanese)

39) Y. Honda, M. Ono, A. Sasaki, I. Uchiyama: Shift of the Short-term Temperature-mortality Relationship by a Climate Factor - Some Evidence Necessary to Take Account in Estimating the Health Effect of the Global Warming, Journal of Risk Research, Vol.1, No.3, pp.209-220, 1998

40) A. E. Kunst, C. W. Looman, J. P. Mackenbach: Outdoor Air Temperature and Mortality in the Netherlands: A Time-series Analysis, Am J Epidemiol., Vol.37(3), pp.331-41, 1993.2

41) Y. Honda, M. Ono, A. Sasaki, I. Uchiyama: Relationship between Daily High Temperature and Mortality in Kyushu, Japanese Journal of Public Health, Vol.42, No.4, pp.260-268, 1995 (in Japanese)

42) M. Ono: Risk of Health Emerging Due to Climate Change Citizen's Role and Response, IGES-WHO International Symposium on climate change and health, 2009. (in Japanese)

43) Y. Doi: Creation of the Japanese Version of the Pittsburgh Sleep Questionnaire, Japanese Journal of Psychiatric Treatment, Vol.13, No.6, pp.755-763, 1998. (in Japanese)

44) M. Tanaka, S. Fukuda, K. Mizuno, K. Imai-Matsumura, T. Jodoi, J. Kawatani, M. Takano, T. Miike, A. Tomoda, Y. Watanabe: Reliability and Validity of the Japanese Version of the Chalder Fatigue Scale among Youth in Japan, Psychol Rep., 103(3), pp.682-690, 2008.

45) National Institute of Environmental Studies, Japan: Information on Heat Stroke Patients, available from <http://www.nies.go.jp/gaiyo/archiv/risk8/index.html>, (accessed 2018-02-15) (in Japanese)

46) Japan Emergency Medical Society Committee on Heat Stroke: Survey on Actual Conditions of Heat Stroke - Japan Emergency Medical Society Heatstroke STUDY 2012 Final Report -, JJAAM, Vol.25 No.11, pp.846-862, 2014. (in Japanese)

47) H. Kusaka, N. Iijima, T. Ihara, M. Hara, Y. Takane, S. Iizuka: Future Projection of Heat Stroke and Sleep Disturbance for 2070's August in Tokyo, Nagoya, and Osaka - Dynamical Downscale Experiments from Multiple CMIP3-GCMs and Health Impact Assessment by Mid-point Type Methodology, Journal of Environmental Engineering (Transactions of AIJ), No.693, pp.873881, 2013.11 (in Japanese)

48) C. J. Murray et al.: Rethinking DALYs, The Global Burden of Disease, Harvard University Press, 1996.

49) H. Yoshikado: One Possible Factor Causing Recent Trend of Photochemical Oxidants, Journal of Japan Society for Atmospheric Environment, Vol.39, Issue4, pp.188-199, 2004. (in Japanese)

50) Y. Takahashi, S. Kawashima, S. Aikawa: Effects of Global Climate Change on Japanese Ceder Pollen Concentration in Air: Estimated Results Obtained from Yamagata City and its Surrounding Area, Japanese Journal of Allergology, Vol.45, Issue12, pp.1270-1276, 1996. (in Japanese)

51) I. Kurane: Effect of Global Warming on Infectious Diseases, AIRIES, Vol.14, No.2, pp.279-283, 2009. (in Japanese)

注

注 1) 重篤度(disability weight) とは疾患の重さを健常の場合を 0 , 死亡の場合を 1 として, 0 から 1 の間で表現する変数であり, 様々な疾患に関する重篤度がデー タベースとして整理されている ${ }^{34)}$ 。一例として挙げると, 食道閉鎖症 (Oesophageal atresia）のように 0.85 と高い值もあれば，喘息（Asthma）のよ うに 0.043 と低い值もある.ただし, 重篤度の調查報告は癌や肺炎などの重篤性 の高い障害が多く, 睡眠困難や疲労などの軽度な障害を評価するためには重篤度 自体の設定に関する調査が必要となる場合が多い

注 2) 本論文では広範に屋外気温と健康影響との関係を評価する。後述する評価対 象には医学的には疾患(disease) とは定義されない障害(disturbance)や症状 (symptom)のような影響も含むが, 本論文の表記上では全て「疾患」と定義する. 後述するDALY では器質的であれ精神的であれ健常状態から外れた場合に 0 以 上の值を持つ。

注 3) DALY は発展途上国における健康損失を始め，世界の健康負荷を計量するこ とを目的に開発された指標であり， Murray et al.48)が Global Burden of Disease $^{34)}$ の研究の一環でWHO と共同開発した. DALY の 1 単位は人間 1 人の 寿命が 1 年損失されることに相当する. なお, DALY は早死による生命損失年数 (years of life lost, YLL) と障害による相当損失年数(years lived with a disability, YLD)の和と定義される．YLL は期待寿命と死亡年齢の差で算出する．YLD は障 害の程度である「重篤度」と障害の期間である「有病期間」の積で算出する。し たがって, 死亡に至る障害を評価するためには, 各疾患について期待寿命と死亡 年齢の差を, 死亡に至らない障害を評価するためには, 重篤度と有病期間を設定 する必要がある.

注 4）1 章で述べたように，その他の影響として光化学オキシダント濃度の上昇に 伴う喘息などの悪化, さらには花粉飛散量の増加によるアレルギー疾患の影響な どが考えられる。しかしながらいずれも原因物質増加のメカニズムや影響に関わ る因果関係などが十分に説明されていない ${ }^{49) 50)}$. したがって, 本論文では冒頭で その可能性について指摘するにとどめ, 定量評価は今後の課題と位置づける.

注 5）人得失法はある特定の健康状態を完全健康状態と比較したときの価值を回答 者に尋ねて測定する手法である，たとえば，完全健康者 10 人の急死を防ぐ保健 施策 $\mathrm{A}$ と完全健康者 $\mathrm{n}$ 人が特定の健康状態に移行するのを防ぐ保健施策 $\mathrm{B}$ とが 二者択一であると仮定し, 両施策が同等の価值をもつような $\mathrm{n}$ につて回答者の 意見を求める。

注 6) Müller-Wenk は夜間騷音による睡眠困難の重篤度を 28 種類の他の疾患との 比較から定義している ${ }^{36}$. 調査の際に提示した疾患は歯周病（重篤度 0.01）から 重度痴呆症 (0.95) まで幅広く選択されている. 調査対象者は医療スタッフ 41 名 であり, 得られた值は算出平均で 0.055 （CI95\%:0.071-0.039）であった.

注 7) 本調査で得られた重篤度はばらつきも大きく, インターネット調査であるた め回答者の重篤度に関する知識が十分ではない可能性も考えられる，そのため今 後はより丁寧な手続きを踏む人得失法など別の手段による結果と比較検証を行 うなどが今後の課題として挙げられる.

注 8) 各記号は ICD-10 と対応している. なお，いずれも重篤度が同程度として評 価されるが，有病期間は異なるものであり，結果として各疾患の DALY は全く 異なる值となることに注意されたい. 例えば, 重度の視力障害は一般的には短期 に回復するものではないが, III度の熱中症は早期に回復する可能性が高い.

注 9）予備力とは「最大能力」と「平常の生命活動に必要な能力」の差を意味し, 老化が進行するほど予備力が低下することで, 平常以上の活動を必要とする事態 が生じたときに対応が困難となる.

注 10）刈り取り効果とはリスクに対して脆弱な人から死亡する可能性が高いこと を表す比喻であり, リスクを取り除いた場合の平均余命も大きく変化しない.

注 11）1 章で述べたように, 将来的には温暖化の進行によりデング熱のような生物 媒介性感染症の影響拡大が懸念されるが, 現時点ではどのような感染症患者がど の程度増加し, 分布地域がどう変化するかについての理解は十分に進んでいない 51)。そのため本論文では都市内で例年確実に発生する感染症のみを対象とした. 注 12）一部医療機関による抜粋調査の対象となる感染症については, 報告医療機関 と地域内の全医療機関との比率を用いて全数を予測した。

注 13）気温変化が感染症に及ぼす影響のメカニズムは未だ解明されていないもの が多く，本論文で得られた相関関係も表面上の関係であり，実際は気温のみなら ず社会的活動などが影響を与えている可能性があることに留意する必要がある. 注 14）各感染症については比較的症状の近い疾患の重篤度が GBDに掲載されてい ることもあり，本論文ではそれらとの比較から決定したが，今後の課題として 3 章で示した熱中症と同様に, 医者に対するアンケートや専門家パネルなどのプロ セスを経て重篤度を決定することが厳密には求められる.

注 15）ここで評価された熱中症発症数はあくまでも救急車により医療機関に搬送 された数であり, 直接医療機関に受診した, あるいは受診しなかった患者も多く 存在すると考えられるがそれらの把握は困難である. 多くは軽症であると予想さ れ，疲労評価に含まれる可能性も考えられる。

注 16) DALY の評価パラメータに関して, 屋外気温や人口の過去から現在にかけて の変化は確実性が担保される。また, 重篤度や有病期間は不変として扱われる. 一方で, 気温感度 (疾患人数) については社会システムや人口年齢構成の変化に 伴って過去から現在にかけてはもちろんのこと, 将来的にも変化する可能性が考 えられる。評価結果について十分な正確性を担保するためにも, 気温感度自体の 時代変化や予測手法の確立が今後の課題として位置づけられる.

注 17) Fig. 6 および 7 からわかるように, 睡眠困難および疲労には屋外気温に依存 しない一定被害が存在する. 本論文の目的は屋外気温変化と健康影響との関係で あるため， 5 章の被害分析では気温に依存する被害量のみを評価対象とする. 


\author{
Daisuke NARUMI ${ }^{* 1}$, Tomohiko IHARA ${ }^{* 2}$, Sanae FUKUDA*3 \\ and Yoshiyuki SHIMODA*4 \\ ${ }^{* 1}$ Assoc. Prof., Graduate School of Environmental and Information Sciences, Yokohama National University, Dr.Eng. \\ *2 Assoc. Prof., Dept. of Environment Systems, University of Tokyo, Dr.Eng. \\ ${ }^{*} 3$ Prof., Dept. of Health and Welfare, Kansai University of Welfare Sciences, Dr.Med. \\ ${ }^{* 4}$ Prof., Graduate School of Engineering, Osaka University, Dr.Eng.
}

Recently, increasing urban temperatures due to the Urban Heat Island (UHI) effect and Global Warming (GW) have been remarkable in some Japanese metropolises. The UHI effect and GW not only cause temperatures to rise, they also have other diverse impacts on urban dwellers. Therefore, it is important to understand the effect of temperature increase on urban dwellers to take action for preventing the occurrence of adverse impact. In this regard, the authors have shown the overall perspective of the effect of temperature change on urban dwellers by relation diagram, and evaluated the influence on energy, resources, health, air pollution etc. as much as possible quantitatively.

This paper aims to comprehensively and quantitatively evaluate the impact of urban outdoor temperature change on human health in Osaka Prefecture, based on the data accumulated by the authors and the results of past researches, conducted an annual evaluation from fatal severe to relatively mild impact. Specifically, based on the concept of endpoint-type life cycle impact assessment method, human health impact due to various diseases was integrally evaluated using DALY (disabilityadjusted life year). The evaluated diseases were heat / cold stress and hyperthermia as fatal severe effect, infections such as Herpangina as relatively severe effect, sleep disturbance, fatigue and mild heatstroke as a relatively mild effect. The time range of the evaluation was from 1967 to 1977 (1970s) as the base period, from 1987 to 1997 (1990s), further from 2007 to 2017 (2010s) over the past 40 years.

The results of this research are described below.

1) With respect to the disability weight that is indispensable for the evaluation of DALY, the value of mild heatstroke was determined by questionnaire survey for 70 physicians with reference to Müller-Wenk's method. The average value was 0.081 for Grade I, 0.237 for Grade II and 0.463 for Grade III.

2) The average comprehensive value of DALY for annual evaluation was particularly remarkable increase in the period from the 1990 s to the 2010 s, it was about four times as much as the change from the 1970 s to the 1990 s.

3) The maximum comprehensive value of DALY throughout each period was recorded in 1994, this indicate slightly different from secular trend of average value and the influence of sudden and intense heat was strong.

4) The minimum comprehensive value in the 2010s was almost the same as the average value of the $1970 \mathrm{~s}$, this showed that DALY increased steadily and extremely low situation did not occur.

5) The comprehensive value of DALY increased from May to October due to the temperature change of 40 years but decreased from November to April. In other words, urban temperature change had a negative impact on health from the early summer to the early autumn, while a positive impact from late autumn to spring.

6) The largest increase of DALY was seen in August, especially deterioration in sleep disturbance, fatigue, death by heat stress and death by hyperthermia showed large impact. On the other hands, the largest decrease was seen in February, mitigation in fatigue and cold stress showed large impact. The annual total value of DALY increased by 2,854 [DALY].

7) The influence of sleep disturbance and fatigue had a large impact on the change in DALY. Although the disability weight and the disease period are small for these disease, these influences are indispensable to evaluate the entire of human health from the macro viewpoint of urban area. 